\title{
Ds Marié Joseph Goddefroy as volksman
}

\author{
SJ Botha
}

\section{Abstract}

\section{The Rev MJ Goddefroy as an Afrikaner patriot}

To honour prof AD Pont, a devoted Afrikaner patriot himself, on his sixtieth birthday ( 21 September), this paper pays attention to the patriutism of the Rev Goddefroy who, one hundred years ago in 1887, came from the Netherlands to the Zuid-Afrikaansche Republiek. Here he not only became a minister of the Nederduitsch Hervormde Kerk, but he also heartily adopted the Afrikaner as his own people and made their ideals his own.

Eenhonderd jaar gelede op 30 September 1987 is ds Marié Joseph Goddefroy bevestig as predikant van die Nederduitsch Hervormde Kerk in die kombinasie Pretoria-Middelburg-Standerton (Trichardsfontein) (Botha 1981: 53, 60). In dieselfde maand, veertig jaar later, is Adriaan Drost Pont op 21 September 1927 te Kroonstad gebore (Botha 1967: 33). September 1987 bied dus die geleentheid om in die een geval na honderd jaar en in die ander geval na sestig jaar gelede terug te kyk. Om prof Pont op sy sestigste verjaardag te huldig, word by hierdie geleentheid na ds Goddefroy as volksman teruggekyk om juis ook erkenning te gee aan die hartstogtelike liefde vir die Afrikanervolk wat so 'n besondere kenmerk van prof Pont se lewe is.

Toe Goddefroy honderd jaar gelede as predikant van die Nederduitsch Hervormde Kerk bevestig is, het hy nie maar net die herderstaf in die genoemde kombinasie opgeneem nie, maar was hy vanaf daardie oomblik en vir die daaropvolgende vier jaar die enigste predikant van die Kerk wat man-alleen dertien gemeentes met sewentien kerkplekke moes bedien (Engelbrecht 1953: 320). Hierdie feitlik bomenslike taak het Goddefroy op hom geneem die oomblik toe hy in Maart 1887, terwyl hy predikant van die Nederlandse Hervormde Gemeente Achlum-Hitzum (Friesland) was, besluit het om die beroep te aanvaar na 'n kerk wat deur die mislukte kerkvereniging van 1885 totaal ontwrig was en sonder die dienste van enige predikant moes klaarkom (Botha 1981: 53). Goddefroy self het hierdie beroep as "n goddelike roeping die door de verlaten Kerk tot my kwam' gesien (Botha 1981: 56). 
Oortuig van die saak van die Nederduitsch Hervormde Kerk, het hy hom met volle oorgawe en met al die gawes van hoof en hart waaroor hy beskik het, tot by sy emeritaat in 1917 daaraan gewy.

Goddefroy het met sy koms vanuit Nederland na Suid-Afrika nie alleen ' $n$ ander kerk 'aangeneem' as dié waarin hy predikant geword het nie, maar dit het ook meegebring dat hy onder 'n ander volk as sy eie sou moes werk. Al is dit waar dat sowel kerklik as kultureel gesproke daar in die vorige eeu baie noue bande tussen Nederland en die Zuid-Afrikaansche Republiek bestaan het, was daar tog ook baie groot en diepgaande verskille. Goddefroy het egter ook die Afrikanervolk as sy eie aangeneem en met groot liefde en vurige patriotisme sy aangenome volk gedien selfs ten spyte van groot offers wat dit van hom gevra het. Dit was nooit vir hom problematies om as kerkmens ook volksmens te wees nie. Trouens dit was vir hom vanselfsprekend dat dit so moes wees juis vanweë sy siening van die noue verbondenheid wat daar tussen kerk en volk moes bestaan.

Reeds baie jare voordat hy na die Zuid-Afrikaansche Republiek gekom het, het Goddefroy ' $n$ besondere belangstelling in en agting en waardering vir die Boere gekoester. Veral die kloeke optrede van die klein vertrapte volkie teen die magtige Britse Ryk gedurende die Eerste Vryheidsoorlog van 1880-1881 het by hom groot bewondering afgedwing. In sy huis was die dapper Boerevolk baie dikwels die onderwerp van bespreking en bewondering en is hierdie bewondering ook na sy kinders oorgedra. Dit was juis hierdie besondere gesindheid teenoor die Transvaalse Afrikaners en hulle kerk, tesame met sy tien jaar ervaring as predikant in die Nederlandse Hervormde Kerk wat hom 'n geskikte kandidaat vir die beroep na die kombinasie PretoriaMiddelburg-Standerton gemaak het.

\section{BEROEP NA DIE NEDERDUITSCH HERVORMDE KERK IN DIE ZUID-AFRIKAANSCHE REPUBLIEK}

Die poging tot kerkvereniging tussen die Nederduitsch Hervormde Kerk, die staatskerk van die Zuid-Afrikaansche Republiek, en die Nederduitse Gereformeerde Kerk wat in 1865-186u onder ds Frans LionCachet van die staatskerk afgeskei het, het klaaglik misluk en selfs groter verdeeldheid en bitterheid as tevore op die kerklike werf van die Zuid-Afrikaansche Republiek tot gevolg gehad (Engelbrecht 1953: 281vv). Die grootste gedeelte van die lidmate van die Nederduitsch Hervormde Kerk was nie vir die vereniging te vinde nie, terwyl die 
grootste gedeelte van die wat wel verenig het, uiteindelik weer na die Hervormde Kerk teruggekeer het.

Een van die probleme vir diegene wat die Nederduitsch Hervormde Kerk gehandhaaf het, was dat hulle geen predikant gehad het nie. Onder leiding van die sogenaamde konsulentsgemeente van Pretoria (soms ook die gemeente Witfontein genoem), wat die enigste gemeente was van die Kerk wat in sy geheel buite die kerkvereniging gebly het, is besluit om soos in 1852 na Nederland te kyk om 'n predikant vandaar te kry (Engelbrecht 1955: 77). 'n Kombinasie tussen die gemeentes Pretoria, Middelburg en Standerton (Trichardsfontein) is gesluit en in Januarie 1887 is ses blanko beroepsbriewe na die gesant van die ZuidAfrikaansche Republiek in Europa, jonkheer dr G Beelaerts van Blokland, gestuur om vir hulle ' $n$ predikant in Nederland te soek. Om aan hierdie versoek te voldoen, het Beelaerts die leiding geneem en ' $n$ komitee gevorm wat bemiddel het dat uiteindelik verskeie predikante uit Nederland na die Zuid-Afrikaansche Republiek sou gaan (Botha 1981: $56,102)$. Een van die lede van hierdie komitee was dr $F$ van Gheel Gildemeester, 'n studentemaat en baie groot vriend van Goddefroy, en hy het geweet dat Goddefroy die geskikte kandidaat was vir die beroep na die Nederduitsch Hervormde Kerk. Uit begeleidende skrywes wat deur die kerkraad van die kombinasie van Beelaerts gerig is, kon die komitee ' $n$ duidelike beeld vorm van die besliste vereiste wat die kerkraad gestel het waaraan hulle kandidaat moes voldoen. Hulle wou veral iemand hê wat die moed en durf en die vermoë sou hê om te alle tye die saak van die Nederduitsch Hervormde Kerk te stel en die eer van die Kerk te handhaaf.

Met die handhawing van die Nederduitsch Hervormde Kerk het hulle baie meer op die oog gehad as bloot die handhawing van die naam Hervormd. Dit het vir hulle gegaan om die handhawing en voortsetting van die kerk wat deur die Voortrekkers die binneland ingedra is en wat in die vestiging van ' $n$ eie onafhanklike staat noord van die Vaalrivier so 'n belangrike en beslissende rol gespeel het. In hierdie kerk was hulle tuis en hulle wou die aard en karakter van die kerk ongeskonde hou. Baie belangrik vir hulle was ook die feit dat hulle die heropbou van die Nederduitsch Hervormde Kerk as van die grootste belang beskou het vir die staatkundig-polities-kulturele vryheid van die Zuid-Afrikaansche Republiek. Dit was veral die ouderling Christiaan JJ Joubert (Duvenage 1969: 110) wat dit onomwonde gestel het dat nie alleen die nood op kerklike terrein die koms van 'n predikant uit Nederland noodsaaklik en dringend gemaak het nie, maar ook die besondere 
betekenis wat dit op staatkundige terrein sou hê. Sy standpunt het hy soos volg in ' $n$ brief aan Beelaerts gestel:

... dat ik by U.E. aandring is niet alleen voor Kerk maar ook voor staat, want hoe meer de godsdienst hier kan versterkt worden door predikanten uit Holland, hoe meer onze vrijheid gewaarborgd is. $U$ kant zelf begrijpen welken invloed het op de bevolking uitoefenen indien de meerderheid van die predikanten alhier van gevoelens Engelsch zijn, en daarom is het voor ons van $z 00$ ' $n$ groot belang. Onze oude Kerk moet in stand gegouden worden, wil men onze vrijheid deurgaans doen blijven. Ook versoek ik U.E. vriendelijk, bij het uitkiezen van een predikant vooral te letten op de geaardheid, oprechtheid en trouw aan de Hervormde Kerk en ook op de bekwaamheid om het ontstaan van de Hervormde Kerk en wat daarvoor geleden en gestreden is aan de bevolking te doen kennen. Ik geloof nooit, dat Holland zijn werkelijk doel om Transvaal goed te doen, zal bereiken, indien men ons geen leeraren toezendt. Daarvan zal het afhangen, want door den omgang met Hollandsche leeraren worden de twee elementen tot een gebracht, en dit is een kracht voor ons land (Engelbrecht 1953: 315).

Joubert se vereiste ten opsigte van die predikant was dus in die eerste plek absolute trou teenoor die Nederduitsch Hervormde Kerk. Gepaardgaande hiermee moes hy bereid en geskik wees om mee te werk aan die bestendiging van die Transvaalse vryheidsideaal. Joubert het dus die handhawing van die Nederduitsch Hervormde Kerk as noodsaaklik vir die handhawing van die staatkundig-polities-kulturele vryheid van die Transvaal beskou. Hierin sou 'n predikant uit Nederland vir die Nederduitsch Hervormde Kerk van groot belang wees. Hierdie siening van Joubert het hom nie 'n eenling in die Nederduitsch Hervormde Kerk gemaak nie. Dit kan aanvaar word as die siening van die Nederduitsch Hervormde Kerk self. Die volgende aanhalings uit twee briewe wat die onderwyser W Louis privaat aan Beelaerts gerig het, onderstreep dit. Op 6 Januarie 1887 het hy geskryf:

De oude hervormde partij is heeltemaal voortrekkers element en Krugergezind (Anti-Kaapsch, Anti-Engelsch), redenen waarom president Kruger ook zoo gaarne de Hervormde Kerk weer op de been zag. 
Op 21 Januarie 1887 het hy onder andere nog laat volg:

Mocht toch de a.s. predikant van die Hervormde Kerk maar een man zijn die bij een vroom gemoed, alle lust heeft om te staan tegenover de Kaapsche partij, wier ernstig streven is om ons zoo spoedig mogenlijk Engelsch te maken.

Gildemeester het geweet dat sy vriend Goddefroy die kandidaat was wat genader moes word en hy en Beelaerts het hom volledig ingelig oor die situasie van die Nederduitsch Hervormde Kerk en die vereistes wat uit die Kerk ten opsigte van die kandidaat gestel is. Benewens die teologies-kerklike vereistes, is ook die staatkundig-polities-kulturele gesindheid en houding van die Nederduitsch Hervormde Kerk, wat sterk Krugergesind en beslis anti-Kaaps en anti-Engels was, onder sy aandag gebring. Goddefroy het dus baie duidelik geweet wat van hom verwag is en van die begin af het hy hom volkome en van harte vereenselwig met sowel die teologies-kerklike koers as die staatkundige en politieskulturele houding en gesindheid van die Nederduitsch Hervormde Kerk. Trouens selfs op die Engelse stoomboot wat die Goddefroy-gesin na Kaapstad vervoer het, het dit geblyk dat by Goddefroy reeds op daardie stadium 'n sterk anti-Engelse gevoel was en hy het geweier om Engels te praat (Goddefroy A s a: 2).

In Transvaal aangekom, het die Goddefroy-gesin en die gesin van ouderling Christiaan Joubert goed bevriend geraak.

Dit was ' $n$ vriendskap wat deur Goddefroy hoog waardeer is en wat lewenslank geduur het. Goddefroy en Joubert was geesgenote en hulle het mekaar maklik gevind. Dit was veral Joubert wat Goddefroy noukeurig ingelig het oor die kerklike en staatkundig-kulturele situasie in die Zuid-Afrikaansche Republiek. Dit het daartoe bygedra dat Goddefroy, wat self skerpsinnig waargeneem het, vinnig 'n heldere insig in die hele problematiek op sowel die kerklike erf as op die volksterrein kon vorm en sy modus operandi daarop kon bou.

\section{GODDEFROY OOR KERK EN VOLK}

Goddefroy was primêr dienaar van die Woord en hieraan het hy absoluut trou gebly tot sy dood. Dit het egter nie vir hom ingehou dat hy hom moes losmaak van die volk nie. Die teendeel het vir hom gegeld omdat daar vir hom ' $n$ baie noue verbondenheid tussen kerk en volk moes bestaan. Daarom is daar op 'n baie vanselfsprekende wyse deur hom aandag gegee aan die verhouding kerk en volk terwyl hy besig 
was met sy primêre taak van reorganisasie van die ontwrigte Nederduitsch Hervormde Kerk. Dit het nêrens so duidelik aan die lig gekom as met die Algemene Kerkvergadering van 1888 , wat die eerste was na die mislukte kerkvereniging van 1885 nic.

Op die Algemene Kerkvergadering van 1888 blyk dit dat die noue verbondenheid tussen kerk en volk vir hom ingehou het dat die kerk ook ten opsigte van die staatkundig-politieke lewe van die volk, 'n roeping en taak het. Dit blyk by die aanvang van die vergadering reeds duidelik as hy die volgende uitspraak maak:

Ook deed het hem genoegen hier velen ouden van dagen onder de aanwezigen te tellen, die de Kerk alzoo vele malen tegen vreemde overheersching hebben verdedigd, en hij verzekerde dat wij nu zullen blijven vasthouden aan de volgende twee fondamentele beginselen, levensvoorwaarden voor de vrijheid van dit land, en grondslagen dierzelfde wet:

Strijd tegen vreemde overheersching

Tegen gelijkstelling met kleurlingen.

Daarom was het voor de Ned. Herv. Kerk onmogelijk zich te vereenigen met het nieuwe Kerkgenootschap, daar dit onder vreemde overheersing staat...

De voorzitter verklaard verder dat de Ned. Herv. Kerk wil voortgaan op het pad en in het richting door onze vaderen afgebakend en zij eischt alleen vrijheid des geloofs (Notule AKV 1888: 7).

Wat in hierdie uitspraak baie duidelik na vore kom, is dat Goddefroy onomwonde, volkome en van harte aangesluit het by die historiese siening van die Nederduitsch Hervormde Kerk ten opsigte van die staatkundig-politieke terrein. Wat hierdie standpunt was, is reeds deur die Algemene Kerkvergadering van November 1853 kortliks so geformuleer:

... burgerlijk vrij en onafhankelijk, wenschen wij dit ook in het kerkelijke...

Hierdie laasgenoemde formulering toon wel in watter noue verband kerk en volk in die vroeë jare van die Zuid-Afrikaansche Republiek deur die kerk self gesien is en inderdaad gestaan het. Uit die uitspraak self is die afleiding al geregverdig dat 'die staatkundig-politieke opvattings van die volk 'n baie besliste stempel op die kerk gedruk het'. Die volk se staatkundig-politieke onafhanklikheid was dus die beweegrede 
waarom die kerk self organisatories selfstandig en onafhanklik wou wees. Terselfdertyd was die uitspraak van die Algemene Kerkvergadering van November 1853 'n ondersteuning en instemming met die volk se vryheidsideaal (Pont [1969]: 207).

Wat hier in gedagte gehou moet word is dat, in die min of meer ongekompliseerde situasie van die vyftigerjare van die vorige eeu, die grense van die kerk en volk in die Zuid-Afrikaansche Republiek feitlik saamgeval het. Daar kan tereg gesê word: 'Die volk was die Kerk, die Kerk het die volk omvat...' Daarom is dit nie so bevreemdend dat die kerk as 't ware die volk gevolg het en die inlywing by die Kaapse Sinode verwerp het omdat die volk dit verwag het nie. Die volk het dit verwag omdat daar twee sake binne die Kaapse Kerk bestaan het wat deur die Transvalers as ' $n$ bedreiging vir hulle vryheidsideaal gesien is, indien die Transvaalse gemeentes organisatories by die Kaapse Kerk ingeskakel sou word. Die twee sake was:

... die mate van seggenskap wat die Kaapse Kerk, kragtens sy Kerkwet, aan die Engelse Owerheid (in kerksake) verleen het en die feit dat die kleurskeidslyn nie in die Kaapse Kerk gehandhaaf is nie (Pont [1969]: 207).

Met sy uitspraak op die Algemene Kerkvergadering van 1888 het Goddefroy hom bewustelik en ten nouste aangesluit by hierdie historiese noue verbondenheid tussen kerk en volk en die historiese staatkundige-politieke koers wat die Algemene Kerkvergadering van 1853 reeds ingeslaan het. Hierdie standpunt het hy ingeneem ondanks die feit dat hy wel besef het dat die omstandighede in 1888 anders was as in 1853 . Dit was vir hom egter geen rede waarom die Nederduitsch Hervormde Kerk sy beginsels ten opsigte van die verhouding kerk en volk en die taak van die kerk op die staatkundig-politieke terrein moes laat vaar nie. Inteendeel die beginsels moes gehandhaaf en voortgesit word en daarom het hy uitdruklik verklaar dat die Nederduitsch Hervormde Kerk sou

voortgaan op het pad en in het richting door onze vaderen afgebakend.

Ook in die 'Broederlijk schrijven', wat van die Algemene Kerkvergadering van 1888 uitgegaan het, het hierdie gedagtes van Goddefroy weerklank gevind, soos uit die volgende aanhalings duidelik blyk:

Onze Kerk, de Nederduitsch Hervormde Kerk, is de Kerk onzer 
vaderen, de Kerk van het volk dat de Republiek heeft gesticht. Vrij in het politieke, wenschten zij nu vooral hunne vrijheid te gebruiken, om boven alles den God der vaderen te dienen; even als den Staat wenschten zij de kerk in te richten, overeenkomstig de heilige verordeningen Gods maar tevens als de waarborg van hare onafhanklikheid.... Onze vaderen wilden zichzelven zijn, geen kerkelijke invloed van onderdanen van Engelsch bestuur: de mannen die de Republiek in het staatkundige gesticht hadden, gevoelde zich ook in staat een eigen Kerk op te richten: voor het volk, om het volk en door het volk! Laat ons het voorbeeld onzer vaderen in eere houden! Het is bewonderenswaardig hoe onze vaderen met vaste stap op den rechten weg zijn voortgegaan.

Uitdrukkings soos 'de Kerk van het volk' en 'voor het volk en door het volk', dui op die noue verbondenheid wat Goddefroy tussen kerk en volk veronderstel het. Hoewel hy nie reeds op die Algemene Kerkvergadering van 1888 die term 'Nationale volkskerk' gebruik nie, is dit tog heel waarskynlik wat hy in gedagte gehad het. Ongetwyfeld het hy, met die noue verbondenheid wat hy tussen kerk en volk veronderstel het, die saak so gesien:

... dat die Kerk as draer van die Evangelie van Jesus Christus daar is ter wille van die volk, ' $n$ volk wat gedoop is, wat opgeneem is in die verbond van God (Pont [1969]: 216).

Ook hierin kom dit na vone dat Goddefroy se gedagtes in lyn gelê het met díe van Hoedemaker wat van die kerk verklaar het:

En niet van de politieke leiders, maar van de Kerk van Christus gaat de kracht uit. $\mathrm{Zij}$ is door God in het middelpunt van het volksleven geplaatst als het hart in het lichaam en onafscheidelik van het lichaam (Hoedemaker, 16 April 1891).

Goddefroy het dus ten nouste aangesluit by die siening van die houding kerk en volk soos dit histories reeds bestaan het in die Nederduitsch Hervormde Kerk. Wesenlike nuwe gedagtes het hy nie na vore gebring nie. Tog wil dit voorkom of hy gesien moet word as die wegbereider dat die gedagtes van Hoedemaker in die verband ' $n$ pad kon vind na die Nederduitsch Hervormde Kerk wat uiteindelik die Kerk se denke oor die 'Christus-belydende volkskerk' gevorm het.

Die vraag kan natuurlik gestel word of Goddefroy in sy siening oor 
die verbondenheid tussen kerk en volk, nie dalk kerk en volk vermeng het en die kerk in die volk laat opgaan het nie. Om hierop te kan antwoord moet dan kortliks nagegaan word wat Goddefroy onder kerk verstaan het. Die probleem is hier dat hy geen volledige ekklesiologie opgestel het nie, maar dat van hom slegs fragmentariese uitsprake oor die kerk voorhande is. By die nagaan van hierdie gegewens word dit wel duidelik dat hy oor die kerk gedink het in terme van die belydenisskrifte. Van hierdie kerk is Jesus Christus, die Heer van die gemeente, die enigste fondament. Daarom verklaar hy met oortuiging:

Ubi Christus, ibi ecclesia! Waar Christus is, daar is de Kerk! Zoo spraken reeds de Apostolische Vaderen; en het blijft tot op dezen dag toe ook onze Kerkbeschouwing! En waar Rome roept: extra Ecclesiam, nulla salus! Buiten de Kerk geen saligheid! daar houden wij onzen dierbaren Bijbel omhoog, met het antwoord der Hervorming: 'extra Christum, nulla Salus!' dat is: buiten Christus is geen behoudenis (Goddefroy, MJ 1890: 26).

Hy maak wel 'n onderskeid tussen die kerk as geloofsobjek en die sigbare uiterlike organisasie van die kerk. Hy stel dit so:

Toch schijnt het ons geenzins overbodig vooraf wel te onderscheiden tusschen de Kerk, die de Christen gelooft, welke is de gemeente waarvan Paulus getuigt (Eph. v: 27) 'dat zij is heilig en onberispelijk'; en de Kerk waartoe iemand door geboorte of geloofsbelijdenis behoort, welke is het Genootschap; en de Kerk, waar de Gemeente placht saam te komen, welke is het gebouw (Goddefroy, MJ 1890: 26).

Die kerk as geloofsobjek is, ten spyte van die uiterlike verdeeldheid, tog een.

'Ek geloof ééne heilige, Algemene Christelijke Kerk', zoo belijd de Christen tot op deze dag toe, niettegenstaande de hoogst treurige ervaringen van scheuring en verdeeldheid in de strijdende Kerk des Heeren ten alle tijde aanwezig (Goddefroy, MJ 1890: 26).

Die eenheid waarom dit hier gaan, hoef egter nie noodwendig uiterlike of organisatoriese eenheid te beteken nie. Waaroor dit wel moet gaan, is eenheid in geloof en in waarheid, wat kan bestaan selfs al sou daar geen uiterlike of organisatoriese eenheid wees nie. Goddefroy het hom 
beywer vir 'een hoogere eenheid, dan die door vergaderingen, reglementen en kerkeraden kan worden bewerkt'.

Wat hierdie eenheid wel ingehou het en hoe dit bestaan, was vir Goddefroy vervat in die volgende woorde van sy voormalige leermeester prof JJ van Oosterzee, wat hy met groot instemming aangehaal het.

Voorzeker de eenheid van 's Heeren Discipelen, om welke Hij in den laatsten nacht heef gebeden, was geen eenheid van begrippen of stelsels, maar van geloof en leven. Doch waar de harten werkelijk met één zin zijn vervuld, daar naderen ook de geesten elkander; en wie gedurig biddend naar waarheid zoeken, staan op den duur niet onverzoenlijk tegenover elkander. In de levende Gemeente des Heeren ligt de verscheidenheid op de oppervlakten maar de eenheid in eene niet onbereikbare diepte. Ware Christenen in verschillende Kerken, staan doorgaans dichter bijeen, dan de schare der belijders in hetzelfde genootschap (Goddefroy, MJ 1890: 66).

Goddefroy het dan ook verskil van byvoorbeeld Bosman en die Nederduits Hervormde of Gereformeerde Kerk (die Verenigde Kerk) oor die eenheid van die kerk. Volgens die uitleg van die Nederduits Hervormde of Gereformeerde Kerk het die woorde van Johannes 17: 11 nie alleen innerlike nie, maar ook uiterlike eenheid op die oog. Hieroor het Goddefroy hom só uitgespreek.

... maar wij zijn zoo vrij in dezen van mening te verschillen, en achten den eenheid waarvan hier sprake is, voor de naulettenden Bijbellezer voldoende toegelicht door het: 'èèn gelijk als wij' waarmede toch nimmer een uitwendige eenheid kan bedoeld zijn. De eenheid tusschen den Zoon en den Vader die' in den hemelen is, zal toch wel nooit met het uiterlijke in verband gebracht kunnen worden (Goddefroy, MJ 1890: 67).

Daarom het hy nie die bestaan van die drie Afrikaanse kerke as ' $n$ groot kwaad en 'n verskeuring van die eenheid van die kerk gesien nie. Hy het ook die feit dat die kerkvereniging in 1885 misluk het, nie gesien as iets wat vir kerk en volk noodwendig onheil ingehou het nie.

Uit die feit dat Goddefroy die begrip 'kerkgenootskap' gebruik, kan nie sonder meer afgelei word dat hy 'n kollegiale kerkbegrip daarop nagehou het, waar die kerk as vrye genootskap gesien is en waarby mense vrywillig kan aansluit nie. Dit kan ook nie afgelei word uit die feit 
dat hy dikwels van die 'bestuursliggame' van die kerk, in plaas van die kerklike regeerliggame of meerdere vergaderings, praat nie. As kind van sy tyd het hy die algemene spreekwyse van sy tyd gebruik. Uit voorgaande fragmente uit sy denke oor die kerk, is dit reeds duidelik dat hy onder kerkgenootskap niks anders verstaan het as 'n bepaalde uiterlike organisasie nie, terwyl hy wat die kerkregering betref, telkens kwalifikasies bygevoeg het waaruit tog na vore gekom het dat hy in reformatoriese sin oor die kerk en die kerkregering gedink het.

Konkluderend kan gestel word dat Goddefroy se denke oor die kerk wel in lyn gelê het met díe van die Bybels-reformatoriese teologie, hoewel hy as kind van sy tyd tog ook in die terminologie van sy tyd oor die kerk gepraat het. Dit is in elk geval duidelik dat hy gedink het in terme van die

... reformatoriese kerk wat die geheel-van-die-volk, die gekerstende volk, omvat (Pont [1969]: 217).

In die geval is dit byna vanselfsprekend dat, wat die verbondenheid tussen kerk en volk betref en veral wanneer dit uitgedruk word in die term volkskerk, die begrip kerk en nie die begrip volk nie, die kwalifiserende was.

Vanuit hierdie kerkbeskouing en beskouing oor die verhouding kerk en volk het Goddefroy as volksman geleef. Dit was vir hom vanselfsprekend dat hy ook 'n roeping, taak en verantwoordelikheid op die volksakker gehad het. Vandaar sy onvermoeide ywer vir die beginsel van Christelik-nasionale onderwys, waaroor reeds tevore meer breedvoerig gehandel is (Botha 1987: 57-71).

Ook het dit vir hom vanselfsprekend ingehou dat hy selfs in geval van oorlog 'n plig tot verdediging van sy volk gehad het en om bereidwillig sy offers te bring.

\section{GODDEFROY EN DIE TWEEDE VRYHEIDSOORLOG 1899-1902}

Aan elke oorlog het Goddefroy 'n afkeer gehad en by geleentheid het hy selfs die Algemene Kerkvergadering van die Nederduitsch Hervormde Kerk gevra:

'Deze vergadering spreken als haar gevoelen uit dat naar Christelijke beginselen elke oorlog verfoeilijk is en in gaat tegen het wet van de Evangelie' (Notule AKV 196: 43).

Hierdie siening in verband met oorlog het nie beteken dat hy sy plig teenoor sy aangenome volk en vaderland sou ontduik toe hy daartoe 
geroep is nie. Die teendeel is waar. Hy was onmiddellik bereid om sy deel te doen en van sy seuns het hy dieselfde verwag. Die patriotisme wat hy by hulle gekweek het teenoor hulle aangenome volk en vaderland, was so diep gewortel dat hulle geen aansporing nodig gehad het nie. Spoedig het hy drie seuns aan die front te Ladysmith, Natal, gehad naamlik Joseph Louis Christian, Anton Francis Christiaan en Marié Theodore. Nog 'n seun, Edmond Abraham wat op daardie stadium nog nie eens sestien jaar oud was nie, het sonder die medewete van sy vader by die Rustenburg Kommando aangesluit en na die Kaapse grens gegaan (Botha 1981: 146).

Goddefroy self het ook met die Boerekommando's saam na Natal getrek met die Bybel as wapen. Op sy 'spider' het hy 'n groot rooi kruis laat verf om oral waar moontlik en nodig die gewondes die eerste versorging te kan gee. Gereeld het hy daagliks godsdiensoefening onder die burgers gelei en hulle vanuit die Skrif bemoedig om in die geloof te volhard. Sy seun Anton het een so 'n geleentheid soos volg beskryf:

Die oomblik was ernstig en die toespraak van Goddefroy indrukwekkend, want hy het van hart tot hart gepraat met die kring van gewapende manne, onder wie ook seuns van 13 jaar en oues van oor die sestig. Vol aandagtige ontroering het ons almal geluister en menigeen het trane in die oë gehad. Na die sing van ' $n$ psalm en ' $n$ hartroerende gebed tot die Here om die burgers moed en $\mathrm{krag}$ te verleen in die ongelyke stryd, het die kommandant weer die woord geneem en net gesê: En nou, burgers, voorwaarts! (Goddefroy A s a: 41).

Gedurende die eerste drie maande van die stryd was Goddefroy deurgaans saam met die Natalse magte met 'n kort tussenpose van 14 dae tuis. In Januarie 1900, terwyl hy weer vir' $n$ besoek tuis was, het die berig hom bereik dat sy seun Edmond naby Colesberg verwond is. Onverwyld het hy sy seun gaan haal en hom in Pretoria kom versorg totdat hy weer op kommando kon gaan. Ook hierdie terugslag kon Goddefroy se geloof en optimisme nie demp nie. Terwyl hy erken het dat die Boere in 'n verskriklike oorlog betrokke was, het hy aan die ander kant tog optimisties daaraan vasgehou dat Engeland spoedig ' $n$ gevoelige slag toegedien sou word. Vir die onverskrokkenheid, kalmte en vernuf van die Boerekrygers het hy groot bewondering gehad. Tog het hy sy optimisme gegrond op die beskikking van God. Daarvan getuig 'n gediggie wat hy geskryf het om op Nuwejaar 1900 aan vriende te stuur. 
By't bulderen van 't kanon

Te midden van den strijd;

Word toch een Nieuwjaarsgroet

$\mathrm{U}$ biddend toegewijd.

Is ' $t$ eind dezer eeuw

vervult met angst en schrik,

Naar aller Eeuwen eind

Richt zich ons aller blik.

Geen angst beklem ons hart;

waar we opzien tot Gods troon:

Volgt ook uit 't kwade ... goed -

$\mathrm{Na}$ wett'gen strijd... de kroon.

In dieselfde gelowige en optismitiese gees het hy vroeg in 1900 ook aan sy vriend Gildemeester geskryf. Dit was sy vaste oortuiging dat Engeland op die lang duur met skande daarvan sou afkom (Botha 1981: 147).

Slegs enkele maande na hierdie skrywes van Goddefroy, het die oorlog so ' $n$ wending geneem dat hy met sy vrou en drie jonger kinders en 'n klompie besittings wat hy kon saamneem, Pretoria net betyds kon verlaat voordat die Engelse dit beset het. Hulle reis het noordwaarts na Warmbad en verder noord gegaan. In die Waterberge het genl Christiaan Beyers die terugvallende en versnipperde Boerekommando's begin organiseer vir die nuwe guerillastryd wat voorgelê het. Vir die volgende jaar het Goddefroy die kommando's en groepe Boere wat in Noord-Transvaal opgetree het, gereeld besoek en geïnspireer. Vermoedelik was dit juis hierdie optrede van Goddefroy wat die Engelse later laat besluit het dat hy 'n krygsgevangene moes wees en nie as 'n nievegtende burger behandel kon word nie.

Juis in hierdie tyd het hy van sy bitterste oomblikke belewe. Die eerste was toe hy sy oudste seun Joseph aan die dood moes afgee. Joseph was 'n luitenant in die verkennerskorps van Danie Theron. In die loop van Oktober 1900 het hy 'n boodskap by genl Beyers afgelewer en toe verneem dat sy vader daar naby op die plaas Middelfontein noord van Warmbad was. Aangesien hy toe reeds uitgeput en siek was, is hy daarheen om sy vader te groet en self te probeer herstel. Dit het geblyk maagkoors te wees en drie dae na sy aankoms is hy oorlede. Anton het die sterfoomblikke van sy broer so beskryf:

Hy het ons gegroet en gevra dat ons 'Rus my siel, u God is Koning' vir hom moet sing. Vader het by sy bed gekniel, sy hand 
vasgehou en die gesang ingesit. Ons almal het rondom sy bed gestaan en sing: ons drie groot broers met ons bandoliers om ons lyf, die twee jongste broertjies en ons enigste sussie, saam met die stiefmoeder. Toe ons die derde versie sing het vader sy hoof oor Joseph se hand gebuig en in woordelose gebed gekniel gebly. By die einde van die gesang het ons besef dat hy sag en kalm die dood ingegaan het... (Goddefroy A : 53-54).

Slegs sowat twee weke later het die volgende skok Goddefroy getref toe sy twee seuns Anton en Marius krygsgevangene geneem en na St Helena gestuur is.

Sy seun Marius sou hy nooit weer lewend sien nie, aangesien hy op 9 Februarie 1901 te St Helena op 'n baie verdagte wyse deur 'n Engelse wag doodgeskiet is (Botha 1981: 148).

In ongeveer Mei 1901 moes Goddefroy, wat dringend mediese versorging nodig gehad het as gevolg van die soveelste malaria-aanval, aan die Engelse oorgee. Sy versoek om so as nie-vegtende burger beskou te word en daarom as sodanig gehandel te word, is deur die Engelse owerhede afgewys.

'Considering the part he has played during the war' het hulle hom as 'n gewone krygsgevangene beskou en is hy uiteindelik na Brits-Indië gestuur waar hy op 30 November 1901 in die krygsgevangenekamp te Trichinopoly aangekom het. Tot sy groot vreugde het Goddefroy sy seun Edmond, wat intussen ook krygsgevangene geneem is, daar aangetref. So verheug was hy oor die herontmoeting met sy seun, dat hy 'n gedig met agt strofes geskryt het om dit op sy agtiende verjaardag op 16 Desember 1901 aan Edmond op te dra. Uit hierdie gedig spreek die vreugde en dankbaarheid, die pyn en hartseer, maar ook die onwrikbare geloof en vertroue in die almag en beskikking van God van 'n vader, 'n gelowige mens, 'n dienaar van die Woord en 'n vurige patriot:

Gegroet, o liefling van mijn zang,

Mijn Edmond, zoon en troue held!

Mijn dank dat God u sparen wou

Zooals hier in mijn lied vermeld.

Heel vriend'lik heeft $\mathrm{Hij}$ ons geleiden.

Zelfs onder druk van daaglijks kruis

Heeft Hy het weerzien ons bereiden,

Hoe ver ons maagdschap ook tuis.

In een kamp aan Oosterse stranden,

Omspannen door wachten en draad, 
Moogd gij uw verjaardag weer vieren,

Zoo goed en zoo kwaad als het gaat.

In't achtiende jaar van uw leven

Gevangen door list en geweld,

Is't negentiende gunstig ontsloten,

Word vrijheid en vreugd' reeds besteld.

Wel wilde ons de Heere beproeven;

Diep in't hart bloed een wond:

Joseph en Marié zijn gevallen.

Ach, voor Hij verlossinge zond.

Maar Gode zij dank, want zy vielen

Voor Vrijheid en Recht: dus met Eer!

$Z y$ leven in't hart hunner dierbren

En eeuwig bij God, onzen Heer.

Zy zijn ons gedurig voor oogen,

En ook slechts een weinig vooruit;

God zal ook die tranen eens droogen

Als Hij ons den Hemel ontsluit.

$\mathrm{O}$, Edmond, houd vast aan den Heere;

Zyn woord, Zyn dienste en zijn Recht.

Die yvert voor Heilige Eere,

Hy der armen twistzaak beslecht!

(Botha 1981: 177).

Vir Goddefroy was dit 'n saak van eer om as dienaar van die Woord sy medegevangenes pastoraal te versorg en hulle op te beur om nie moed te verloor nie. Ten spyte van sy swak gesondheid en sy groot hartseer oor sy seuns wat geval het, het hy tog nie in wanhoop versink oor die toekoms nie. Nêrens het sy geloof en vertroue so duidelik geblyk as uit 'n diens wat hy op Oujaarsaand, 31 Desember 1901, in die kamp gehou het nie. Sy teks by die geleentheid was 'Kinderkens, het is de laatste ure' (1 Joh 2: 18a). In die slotparagrawe het hy onder andere gesê:

Heeft niet de Almachtige, Schepper des Hemels en de Aarde, al Zijn kracht en Heerlijkheid gelegd in dien Eenen, die lag in Bethlehem's kribbe; die hing aan het Kruis der vervloeking en die komt op de wolken des Hemels!

Wat zyt gy vreesachtig gij kleingeloovigen? Voorzeker, de toekomst is donker; - maar toch in goede milde Handen! 
Daarom geliefde Broeders! die God vreezen - hebben niets te vreezen (Botha 1981: 148).

Goddefroy, wat reeds vroeër so skerp anti-Engels was, was na die dood van sy twee seuns en sy eie krygsgevangeskap en díe van sy ander twee seuns, uiters verbitter teen die Engelse. Daarom het hy dikwels skerp dinge teen hulle kwytgeraak wat hom in botsing met die kampowerhede gebring het. Die uiteindelike gevolg was dat hy vanaf Maart 1902 as 'n sogenaamde 'undesirable' na 'n strafkamp te Fort Govindghur naby Amritsar in die Punjab (Noord-Indië) gestuur is om daar soos ' $n$ gewone misdadiger opgesluit te word (Goddefrov A s a: 88).

$\mathrm{Al}$ sy besware het niks gehelp nie en sy reeds geknakte gesondheid is in daardie ongesonde streek net verder geknou. Nadat die vrede van Vereeniging op 31 Mei 1902 tot stand gekom het, het hy op 9 Julie 1902 die eed van getrouheid aan die Britse kroon afgelê. Sy repatriasie na Suid-Afrika is egter voortdurend vertraag en deur middel van vriende en op eie koste het hy eers na Nederland gegaan in die hoop om daar by goeie mediese dienste te kom en sy geknakte gesondheid ' $n$ kans op herstel te bied. Sy hart was egter by sy aangenome volk in Transvaal en daarheen wou hy terug so gou hy kon. Daarom het hy in 'n onderhoud met die korrespondent van die Nederlandse koerant De Telegraaf van 21 April 1903 verklaar: 'en wat mij betreft, ik hoop te werken zoolang het voor mij dag is, in't belang van mijn natie, die ik liefheb, en die recht heeft op mijn terugkeer. God leidt de harten en bepaald ons lot.'

Ten spyte van die groot persoonlike offers wat hy moes bring in belang van die Afrikanervolk wat hom hartseer en geknak agtergelaat het, was hy tog nie wanhopig nie. Hy het steeds bly vashou aan die beginsel van die Voortrekkerideaal soos hy dit in die Nederduitsch Hervormde Kerk aangetref het en waarby hy hom volkome aangesluit het. Hierdie beginsels was na sy oortuiging voorwaarde vir die voortbestaan van die Nederduitsch Hervormde Kerk as 'de nationale volkskerk'. Dit het hom ná die Tweede Vryheidsoorlog in botsing gebring met gedagtes en ideale wat toe van verskillende kante sterk gepropageer is. Eerstens was daar die verengelsingspolitiek van die Britse Hoëkommissaris Lord Alfred Milner, terwyl reeds kort na die oorlog die Boeregeneraals Louis Botha en Jan Smuts 'n nuwe ideaal van samewerking en konsolidasie met die Engelse imperiale owerheid na vore gebring het. Botha se leuse van 'Vergewe en Vergeet' was vir Goddefroy, wat so swaar moes dra aan die laste wat die onreg van Engeland op hom gelaai het, ten ene male onaanvaarbaar. Ongelukkig het hierdie 
sterk houding teenoor alles wat Engels was vir Goddefroy heelwat botsings meegebring, selfs met kerkleiers binne die Nederduitsch Hervormde Kerk (Botha 1981: 162).

Sy geknakte gesondheid, sy groot hartseer oor sy kinders, asook ander ontwrigtende gebeure het veral in die jare direk na die oorlog tot gevolg gehad dat hy baie van sy vegters-vurigheid van voor die oorlog verloor het. Heeltemaal het hy dit nooit verloor nie en nog in 1916 het sy skerp anti-Engelse houding nog weer duidelik na vore gekom as hy soos volg antwoord op 'n uitnodiging van die burgemeester van Middelburg na 'n sogenaamde Verootmoedigingsdiens waar vir Engeland se oorlogspoging gebid moes word:

... dat ik, ofschoon de uitgesproken bedoeling van deze Oproep waarderende, toch niet zou deelneem aan deze uitnodiging, omdat ik een innerlijke afkeer gevoel niet alleen van alle oorlog (buiten de oorloogen des Heeren, die uit den aard der zaak geestelijk behoort te zijn) maar evenzeer van alle dergelijke, politiek-religieuse demontraties ' (als waartoe wij thans worden opgeroepen) en dat, terwijl de handen nog rooken van het bloed der naaste; en de oude Kainswerk onverdrooten wordt voortgezet!

Voor ons Hollandsprekende Afrikaners te afschuwelijker, omdat wij - als Afrikanernatie - pas onlangs het duurste offers hebben betaald voor onze vrijheid en onafhankelijkheid; die onmisbare - goederen voor alle sich zelf respekteerende menschen! Terwijl wij nu weer betrokken worden in een oorlog, die de onze niet is, en ook niet kan zijn; nietegenstaande wij formeel daarin werden gesleept, op grond van relaties, voortvloeiende uit zoogenaamd oorlogsrecht, dat ten slotte niet anders is dan (wat wilt ge?): het hoogste onrecht; of het laagste!

Selfs twee jaar na sy aftrede, terwyl hy liggaamlik al so verswak het dat hy slegs nog met moeite kon beweeg, was daar nog die opflikkering van die ou vurigheid waar dit die Afrikanervolk geraak het. Daarom het hy nog in 1919 die volgende telegram aan die sogenaamde 'Onafhanklijkheids Deputatie' gestuur.

Gods beste zegen op edel poging tot rechtverkrijging voor een edel volk dat even als ikzelf - onder protest (vi coactu) als prisonier in Indië eed van getrouwheid heb moeten afleggen - als voorwaarde om weer tot mijn volk en Gemeente te Pretoria te mogen terugkeren; enkel omdat ik als Leeraar mijner Kerk onge- 
wenst geacht werd, en terecht want dat ben en blijf ik voor alle dieven, rovers en moordenaars in't groot en klein: ... Eere die Helden, die op hope tegen hope, aan't Heilig Recht blijven vasthouden tot het einde toe; zo hebben ook onze Vaderen gedaan staande met God alleen. $U$ weet ik heb mij gedurende veertigjarige ambtsbediening nooit bij enige politieke partij aangesloten maar als dienaar van Christus zo na mogelijk bij recht den wet. Daarom hartelike zegenhede op uw poging voor een schijnbaar verloren zaak en reeds Imperiaal ingedeeld volk, van uw zeventigjarige oud-Leraar en Ex-banneling om der vrijheidswil; Vader van twee dierbare zoonen, slachtoffers van Engelands gruwelen gepleegd aan Vader, Moeder en kinderen der Souvereine Republieken van Zuid-Afrika. Eerbiedig Saluut! (Botha 1981: 213).

Dit was volkome waar wat prof $\mathrm{dr}$ JHJA Greyvenstein in sy prediking by die begrafnis van Goddefroy op 12 Augustus 1920 in verband met laasgenoemde as volksman gesê het:

Liefde tot de Afrikaners en 'n vast geloof in hun toekomst bracht ds Goddefroy naar dit land. De lijfspreuk van de overledene was, en deze woorden stonden geschreven op die eerste bladsij van z'n veelgelezen $\mathrm{Bijbel,} \mathrm{-} \mathrm{amo} \mathrm{-} \mathrm{ik} \mathrm{het} \mathrm{lief,} \mathrm{en} \mathrm{credo} \mathrm{-} \mathrm{ik} \mathrm{geloof.} \mathrm{De}$ overledenen had s'n aangenomen vaderland zo lief, toen't in moeilikheden geraakte en de oorlog van 1899 uitbrak, hij dadelik vier van zijn zoons zond om te vechten op't slagveld en zelf naar buiten naar de kommandos ging om woorden van troost en aanmoediging tot de burgers over te brengen.... Afrika was zijn land geworden en het Afrikaans volk zijn volk. In zijn hart stond geschreven: Afrika eerst en Afrika voor Afrikaners. Er was een tijd dat ds Goddefroy invloed had op het openbare leven van't volk in Transvaal. In de dagen van de Republiek was hij een van die mannen, met wie rekening gehouden moesten worden.... Zijn invloed had hij altijd gebruikt voor het hoogste belangen van zijn volk. Voor die belangen heeft hij en zichself en zijnen opgeofferd.

Daarom sal die slotwoorde van prof Greyvenstein se rede ook altyd onthou moet word:

Ds Goddefroy had $z$ 'n fouten en gebreken .... maar wie onzer is volmaakt? Zal men dan nog denken aan de kleine onvolmaaktheden bij ' $n$ man die zovele diensten bewees aan Kerk, Volk en Land? (De Volkstem, 17 Augustus 1920). 


\section{Literatuurverwysings}

BOTHA, SJ 1981. Ds Marié Joseph Goddefroy 1848-1920. Pretoria: Kital.

BOTHA, SJ 1987. Ds MJ Goddefroy en Christelik-nasionale onderwys. HTS 43, 57-76.

BOTHA, S] 1967. 1930-1967 in Gedenkalbum Teologiese Fakulteit 1917-1967. Pretoria.

DUVENAGE, GDJ 1969. Ouderling CJ] Joubert, in Nederduitsch Hervormde Gemeente Bronkhorstspruit 1869-1969. Krugersdorp: NHW Pers.

ENGELBRECHT, SP 1953. Geskiedenis van die Nederduitsch Hervormde Kerk van Afrika. 3de Druk. Pretoria-Kaapstad.

ENGELBRECHT, SP 1955. Die Nederduitsch Hervormde Gemeente Pretoria 1855-1955. Pretoria.

GODDEFROY, A [s a]. Die lotgevalle van ' $n$ Hollandse leraar en sy familie. Ongepubliseerde geskrif in die Nederduitsch Hervormde Kerkargief, Pretoria.

GODDEFROY, MJ 1890. Die kerkkwestie: Niet een leer- maar een levenskwestie. Den Haag. HOEDEMAKER, PhJ 1891. De Gereformeerde Kerk, 16 April 1891. Aangehaal deur JH Langeman 1950, Kuyper en de volkskerk. Kampen.

PONT, AD [1969]. Kerk en volk. HTS 25, 202-218. 